\title{
Homicide with a Captive Bolt Pistol
}

\author{
Peter Betz, M.D., Helmut Pankratz, M.D., Randolph Penning, \\ and Wolfgang Eisenmenger, M.D.
}

\begin{abstract}
A homicide with a captive bolt pistol (slaughterer's gun) is reported. The construction and the function of this "humane killer" as well as the typical patterns of injury are described.

Key Words: Homicide - Captive bolt pistol_- "Humane killer"-Slaughterer's gun.
\end{abstract}

There are two kinds of bolt pistols, distinguished according to their construction and function: captive bolt pistols and stud guns. Captive bolt pistols are used for stunning cattle before slaughtering, whereas stud guns are used for driving a hardened metal pin or threaded stud into masonry or other wood or metal structures as a rapid and convenient means of attachment.

Forensically, stud guns are mainly seen in suicidal or accidental injury (1). In the English literature, isolated case reports exist on suicides with free-bullet "humane killers" (2). To the best of our knowledge, there are no reports of fatalities caused by captive bolt pistols in the English-language literature-in contrast to in the German forensic literature.

Captive bolt pistols are made in such a way that injuries can occur only when these pistols are fired from a distance of $<10 \mathrm{~cm} \mathrm{(3),} \mathrm{so} \mathrm{homicides} \mathrm{with}$ such weapons are extremely rare.

Since case reports of homicide by captive bolt pistol apparently do not exist in the English-language forensic literature, we report such a case here.

\section{CASE REPORT}

A 46-year-old railway worker, M.G., had been unemployed for -9 years because of alcoholism and resulting epileptic seizures. He was described as being highly aggressive toward his wife and children and extremely jealous. He did not allow his wife to leave the house alone. For several years, she had not been allowed to take a job in spite of the financial problems of the family.

One year earlier, he had been diagnosed as having a hypopharynx carcinoma and underwent a laryngectomy. Since then, he had not been able to speak. He had been informed about the poor prognosis of his disease. On the night of October 4, 1991, at 3:15 a.m., a witness observed M.G. spreading a transparent plastic bag full of blood on
From the Department of Legal Medicine, University of Munich, Germany. Department Head (W.E.).

Address correspondence and reprint requests to P. Betz, M.D. Department of Legal Medicine, University of Munich, Frauenlobstr. 7a, 8000 Munich, Germany. 
the floor of the hallway. Blood trails were also found on the way to the cellar and the apartment where he lived. The next day, his wife did not appear at work.

On request, M.G. stated that his wife had left the house at 5:00 a.m. to travel to Munich. Her money and identity card, however, were found in the apartment. In addition, partially wiped-away trails of blood were on the floor and extensive blood tracks were on an armchair and a nearby wall in the apartment. In explanation, the man said that he had slapped his wife during a fight and caused her nose to bleed. He denied having killed her, but the next day, she was found dead, wrapped in a transparent plastic bag in the cellar. Around her head was an additional plastic bag.

\section{AUTOPSY FINDINGS}

Two typical injuries caused by a captive bolt pistol were found on the victim's head. A wound that was present in the central occipital region showed no signs of powder burns on the skin or hair. The skull was destroyed in a circular area, $11 \mathrm{~mm}$ in diameter, in the tabula externa. The diameter was greater in the interior of the skull. The path of the bolt was localized to the interhemispheric fissure, but had destroyed parts of both gyri cinguli, especially on the left side of the brain. Along the path of the bolt were hairs and bone fragments. At the end of the path was the punched-out fragment of skin and bone. The second wound (Fig. 1), which was in the center of the forehead, showed a centrally located circular entrance wound with two symmetrically placed powder soot deposits from the gas openings in the distal end of the muzzle that were caused by pressing the captive bolt pistol against the head. The frontal bone had a circular defect 11 $\mathrm{mm}$ in diameter in the tabula externa, with a greater diameter in the tabula interna. At the end of the bolt path were the punched-out pieces of skin and skull. The bolt had lacerated the right frontal lobe, torn apart the right optical nerve, and destroyed the right corpus striatum. The third cerebral ventricle was full of blood.

Furthermore, signs of cerebral pressure as well as subarachnoidal and subdural bleeding were present, blood was found in the trachea and in the bronchial tree, and intrapulmonary signs of moderate blood aspiration were present.

The man gave no further statements, but, 18 days after the homicide, the used captive bolt pistol (Fa. Kerner, model 289, no. 200757, Suhl, Germany; Fig. 2) was found in the bedroom. The man died 1 month later of tumor cachexia and pneumonia while awaiting trial in prison.

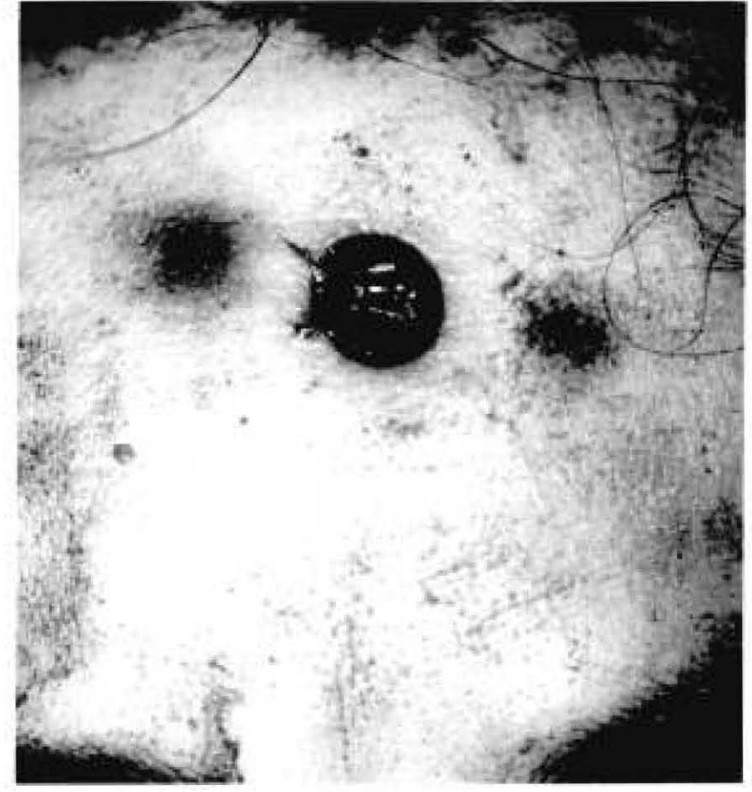

FIG. 1. The injury to the forehead (second shot): a circular skin lesion (diameter of the wound, $11 \mathrm{~mm}$ ) with symmetrically localized powder burns due to tight contact between the captive bolt pistol muzzle and the head when the slaughterer's gun was fired.

According to the police investigation, M.G. had acquired the captive bolt pistol in a specialty store. He had approached his wife while she was sitting or possibly sleeping in the armchair and then fired the slaughterer's gun into her occipital region from a short distance. The gun was not in tight contact with the head at the moment of firing, which explained the lack of powder burns on the adjacent skin or surrounding hair. After the victim was unconscious, the man apparently reloaded the gun and fired a second time.

The motive for the homicide was assumed to be the extreme jealousy of the man, who did not want to "lose" his wife to any other man.

\section{DISCUSSION}

Slaughterer's guns used in Germany consist principally of a muzzle from which a bolt is driven by the discharge of a blank cartridge. The end of the

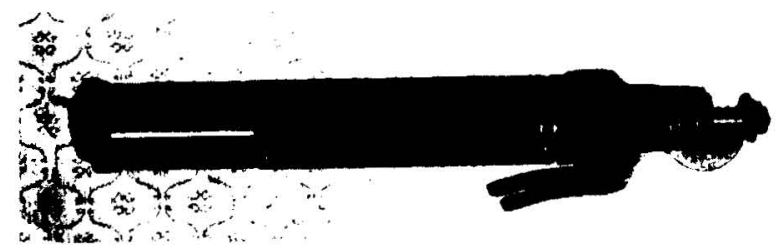

FIG. 2. The captive bolt pistol used (Fa. Kerner, model 289, Suhl, Germany). 


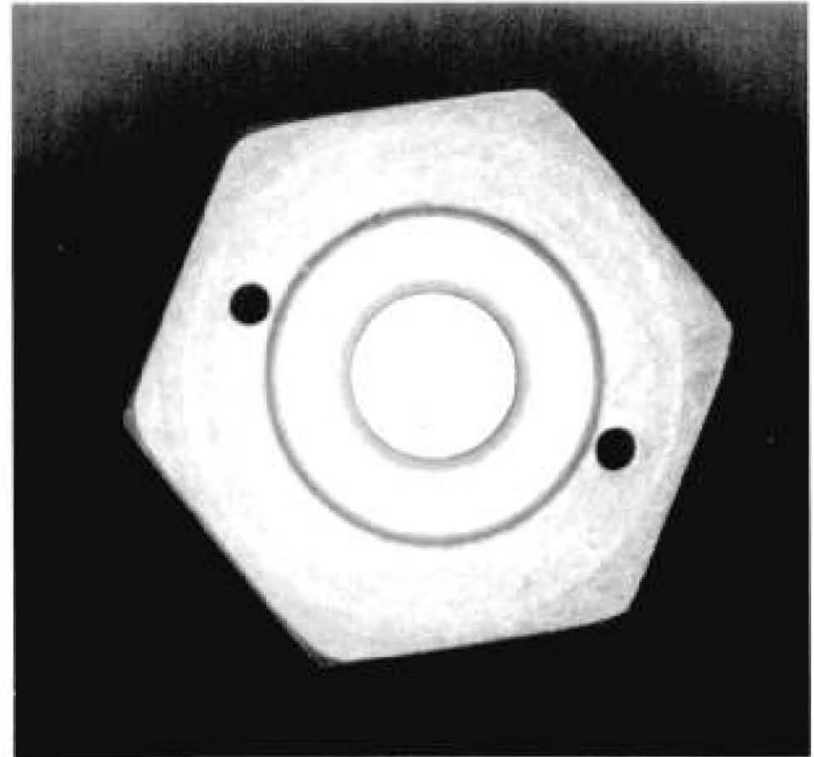

FIG. 3. The distal end of the muzzle showing two openings leading to the symmetrically localized signs of soot deposits around the skin injury.

bolt is usually excavated (rarely spherical), with a diameter of $7-12 \mathrm{~mm}$, depending on the model. The length of bolt ranges from 7 to $12 \mathrm{~cm}$. Therefore, injuries can be expected only if the gun is fired from a distance of less than the bolt's length. According to Janssen and Stieger (3), this distance is $<10 \mathrm{~cm}$.

After firing, the bolt is withdrawn by compressed air or by a spring. A rubber sleeve and a plateaulike widening of the proximal part of the bolt prevent any free bullet flight. Certain manipulations of the instrument, however, enable free flight of the bolt (4).

At the distal end of the muzzle, 2-4 openings that serve as outlets for the gas (Fig. 3) produce the powder soot deposits that occur from discharging the cartridge. The style of the end of the bolt and these openings in cases of tight contact between the skin and the slaughterer's gun produce the typical pattern of injury, which is characterized by a sharp, circular lesion of the skin and the underlying bone (usually the skull) having a diameter that is a little smaller than that of the bolt (3). In cases in which the slaughterer's gun is pressed to the body, especially to the head, the skin injury is flanked by two (or four) symmetrically localized circular areas of powder soot deposits corresponding to the openings on the distal end of the muzzle. If the type of captive bolt pistol used is known, the distance between the soot deposits on the skin enables an estimation of the distance from which the slaughterer's gun was fired (5). With increasing distance, the intensity of the soot deposits decreases, finally dis- appearing. The captive bolt pistols described by Hunt and Kon (2) are similar to the "humane killers" used in Germany, but have no gas outlets at the end of the muzzle. Therefore, no typical powder soot deposits are present, even in cases in which the slaughterer's gun is pressed to the skin.

When the head is injured, the punched-out hole in the tabula externa of the skull is almost exactly the diameter of the bolt. The inner part of the skull, however, shows an increased diameter because fragments of bone are torn out of the skull by the penetrating bolt (3). In the path of the bolt are hairs and bone fragments. At the end of the path is the punched-out part of the skin and the underlying skull. The length of the path exceeds the length of the penetrating bolt for a few centimeters because the bone fragments torn out of the skull act as a "secondary bullet" (6).

The bolt penetrating the skull usually causes immediate unconsciousness, as demonstrated in experimental animals by a loss of visually evoked potentials (7) as well as a loss of corneal reflexes, depending on the localization of the injury $(8,9)$. It has also been shown in experimental animals, however, that captive bolt injury of the brain is not necessarily associated with unconsciousness $(9,10)$ and that cerebral function can-at least partly-be restored, as indicated by the reappearance of acoustically or visually evoked potentials (11). This explains the ability of people to act after sustaining a penetrating bolt injury of the skull $(4,5)$. Indeed, Schliermeyer (12) described a case of suicide by repeated shots from a slaughterer's gun.

The brain injury rarely leads to immediate death, and survival times up to several weeks have been described (5). The prognosis of such injuries, however, is very poor and the mortality rate usually ranges between $80 \%$ and $90 \%$. In this context, in addition to the destruction of brain areas and laceration of intracerebral arteries, the punched-out fragment of skin in the brain determines the prognosis. This bacterially contaminated fragment is responsible for the development of pyogenic meningitis that leads to cerebral dysregulation and death $(4,5)$. Relevant survival times usually occur only in victims of suicide attempts or accidents. In homicides, a second injury after the victim has lost the power to act because of the first shot-as in our casecan easily be inflicted. Pollak (13) describes a homicide victim with two bolt injuries on the occipital part of the head. In this case, the shots had been fired after the victim was unconscious from other causes.

The fact that relevant injuries can be observed only if the captive bolt pistol is fired from a distance 
of $<10 \mathrm{~cm}$ restricts the number of case reports dealing with homicides [for reviews, see Pollak and Maurer (5) and Lignitz et al. (14)] since only defenseless or surprised persons can be hurt. In contrast to the German literature, few English-language case reports of fatalities by captive bolt pistols can be found. Hardt-Madsen and Simonsen (15) listed gunshot fatalities in Denmark in 1970-1979 and reported 15 suicides, one accident, and one homicide caused by "patent killers," but no information was provided on the kind of "patent killers" used. Other publications in English dealing with captive bolt fatalities, especially homicides, were not found.

We therefore used the present case, which occurred in 1991, as an opportunity to report on this type of homicide.

\section{REFERENCES}

1. Weedn VW, Mittleman RE. Stud guns revisited: report of a suicide and literature review. J Forensic Sci 1984;29:6708.

2. Hunt AC, Kon VM. The patterns of injury from humane killers. Med Sci Law 1962;2:197-203.

3. Janssen W, Stieger W. Verletzungen durch BolzenschußApparate unter besonderer Berücksichtigung der Spurenmerkmale. Arch Kriminol 1964;134:96-102.

4. Pollak S, Reiter C. "Bolt projectiles" discharged from modified humane killers [Über die Entstehung von "Bolzengeschossen" bei Verwendung präparierter Viehbetäubungsapparate]. Z Rechtsmed 1981;87:279-85.

5. Pollak S, Maurer H. Zur klinischen Bedeutung der Imprimate bei Verletzungen durch Schlachtschußapparate. Acta Chir Austriaca 1987;1:29-37.

6. Gerlach J. Über Bolzenschußverletzungen des Gehirns. Zentralbl Neurochir 1955;15:83-9.

7. Daly CC, Kallweit E, Ellendorf F. Cortical function in cattle during slaughter: conventional captive bolt stunning followed by exsanguination compared with shechita slaughter. Vet Rec 1988;122:325-9.

8. Dennis MB Jr, Dong WK, Weisbrod KA, Elchlepp CA. Use of captive bolt as a method of euthanasia in larger laboratory animal species. Lab Anim Sci 1988;38:459-62.

9. Lambooy E, Spanjaard W. Effect of the shooting position on the stunning of calves by captive bolt. Vet Rec 1981;109:359-61.

10. Lambooy E. Some features of electrical and mechanical stunning in ruminants [Enige aspecten von elektrische en mechanische bedwelming bij herkauwers]. Tijdschr Diergeneeskd 1982;107:961-6.

11. Daly CC, Whittington PE. Concussive methods of preslaughter stunning in sheep: effects of captive bolt pistol stunning in the poll position on brain function. Res Vet Sci $1986 ; 41: 353-5$.

12. Schliermeyer H. Suizid durch zweimaligen Bolzenschu $\beta$ in den Kopf. Arch Kriminol 1973;151:87-90.

13. Pollak S. Morphology of injuries by "humane killer" (livestock stunner) [Zur Morphologie der Bolzenschußverletzung]. Z Rechtsmed 1977;80:153-65.

14. Lignitz E, Koops E, Püschel K. Tod durch Bolzenschußgeräte. Arch Kriminol 1988;182:83-93.

15. Hardt-Madsen M, Simonsen J. Firearms fatalities in Denmark 1970-1979. Forensic Sci Int 1983;23:93-8. 